\title{
Nutritive value of Acacia tree foliages growing in the Limpopo Province of South Africa
}

\author{
H.K. Mokoboki, L.R. Ndlovu\#, J.W. Ng'ambi, M.M. Malatje and R.V. Nikolova \\ School of Agricultural and Environmental Sciences, University of Limpopo, Private Bag X 1106, Sovenga 0727, \\ South Africa
}

\begin{abstract}
Acacia trees form the third largest woody plant family in southern Africa and are an important ecological component of the bushveld vegetation that is prevalent in the Limpopo Province of South Africa. The purpose of the study was to determine types and amounts of tannins and also to evaluate the nutritive value of tree foliages, Acacia karroo, Acacia nilotica, Acacia tortilis, Acacia galpinii, Acacia sieberiana, Acacia hebeclada and Acacia rhemniana, grown in the Limpopo Province and also to determine types and amounts of tannins occurring in them. Young leaves with petioles from seven tree foliages were collected from five different trees per species at the University of the North (now University of Limpopo) in April 2003, in a completely randomized design. Packed volume ranged from $1.50 \mathrm{~mL} / \mathrm{g}$ for $A$. karroo to $3.00 \mathrm{~mL} / \mathrm{g}$ for $A$. hebeclada whilst water retention ranged from $3.71 \mathrm{~g} / \mathrm{g}$ for $A$. galpinii to $4.98 \mathrm{~g} / \mathrm{g}$ for $A$. sieberiana. These results suggest that all the tree leaves have a high intake potential. All the Acacia species had crude protein levels above $100 \mathrm{~g} / \mathrm{kg}$ dry matter (DM), ranging from $103 \mathrm{~g} / \mathrm{kg} \mathrm{DM}$ for A. rhemniana to $183 \mathrm{~g} / \mathrm{kg} \mathrm{DM}$ for A. sieberiana. Crude protein levels of this magnitude in a diet are adequate to support the maintenance requirements of cattle, sheep and goats at low to medium production levels. The Acacias contained medium to high levels of neutral and acid detergent fibres with ranges of 488 to 622 and 415 to $545 \mathrm{~g} / \mathrm{kg}$ DM, respectively. In vitro DM and organic matter degradabilities varied from 345 to 534 and 254 to 474 g/kg DM, respectively. Acacia hebeclada, A. sieberiana and A. galpinii contained traces of total phenolics whilst $A$. tortilis contained approximately $90 \mathrm{~g} / \mathrm{kg} \mathrm{DM}$ of total phenolics and A. karroo, A. nilotica and A. rhemniana contained intermediate concentrations. Extract condensed tannin (CT) content ranged from $1.1 \mathrm{~g} / \mathrm{kg}$ in A. hebeclada to $80.7 \mathrm{~g} / \mathrm{kg}$ in A. karroo. At level above $50 \mathrm{~g} / \mathrm{kg}$, CT tends to negatively affect intake and digestibility in ruminants. Consequently, reduced intakes of $A$. galpinii, A. karroo and $A$. tortilis could be expected because they contained CT values above $50 \mathrm{~g} / \mathrm{kg}$. Only $A$. nilotica showed a sharp curve in the potassium iodate test, reflecting its considerable content of hydrolysable tannins (HT). All the other species had flat curves reflecting low levels of HT in them. The results showed that all the species except for A. galpinii, A. karroo and A. tortilis are of good nutritive value and have a potential for integration into livestock feeding systems in the Limpopo Province.
\end{abstract}

Keywords: Foliage, tannins, nutritive value, Acacia, packed volume, water retention

\# Corresponding author. E-mail: Irndlovu@nust.ac.zw

\# Present address: National University of Science and Technology, P.O. Box AC 939, Ascot, Bulawayo, Zimbabwe

\section{Introduction}

Inadequate amounts and low feed quality result in reduced livestock productivity in tropical countries. In the Limpopo Province of South Africa ruminant livestock productivity is very low especially during the dry season, when there is a shortage of protein. Acacia trees form the third largest woody plant family in southern Africa and are an important ecological component of the bushveld vegetation that is prevalent in the Limpopo Province. Because of their widespread distribution in the province, they offer a potentially suitable source of supplemental protein for ruminant livestock which would improve their intake and digestibility of native pasture. This should result in improved animal performance (Norton, 1994; Abdulrazak et al., 1996). Their use has been limited by the scarcity of information relating the amount and types of tannins they contain which would affect animal performance. The toxic or anti-nutritional effects tend to occur in times of stress when a very large 
proportion of the diet is tanniniferous. With a better understanding of their tannin properties and proper management, they could become invaluable sources of protein for strategic supplementation. The main objective of this study was to determine the nutritive value of Acacia tree foliages based on physical properties, chemical composition including tannin content and in vitro digestibility.

\section{Materials and Methods}

The experiment was conducted at the University of the North (now called University of Limpopo) in April 2002. Young leaves with petioles from the foliages of Acacia karroo, Acacia nilotica, Acacia tortilis, Acacia galpinii, Acacia sieberiana, Acacia hebeclada and Acacia Rhemniana were collected from five different trees per species. The experimental design was a completely randomised design. After collection, the young leaves were left to dry at room temperature in a well-ventilated laboratory until a constant dry weight was reached, and then stored in brown paper bags pending grinding. Dry herbage was ground to pass through a $1 \mathrm{~mm}$ screen for analysis of dry matter (DM), organic matter $(\mathrm{OM})$, nitrogen $(\mathrm{N})$ and detergent fibres. Samples for polyphenolic analysis were further ground to pass through a $0.2 \mathrm{~mm}$ screen.

Packed volume and water retention were determined using the methods described by Seoane et al. (1981). Forage samples were analysed for $\mathrm{N}$ concentration, using the Kjeldahl procedure (AOAC, 1984), and neutral (NDF) and acid detergent fibre (ADF) levels using the method of Van Soest (1983) as modified by Van Soest et al. (1991). In vitro enzymatic degradability was determined by the method described by Aufrere \& MichaletDoreau (1988). Total phenolics were determined using Folin-Ciocalteau methods and expressed as tannic acid equivalent (g/kg DM) (Waterman \& Mole, 1994). Condensed tannin (CT) was determined using the Butanol$\mathrm{HCl}$ method and expressed as leucocyanidin equivalent (g/kg DM) (Porter et al., 1986) and hydrolysable tannin (HT) levels were determined using the potassium iodate method (Willis \& Allen, 1998). Radial diffusion was determined using the method described by Hagerman (1987).

Analyses of variance were used to test for effect of species on chemical composition, physical characteristics and in vitro enzymatic degradability, using the general linear model procedure of the statistical analysis systems (SAS, 1998), for completely randomized design. If significant P values occurred, separation of means was done using the probability of difference (pdiff) facility of SAS. Correlation was used to measure the degree of association between variables.

\section{Results}

There were significant species effects $(\mathrm{P}<0.05)$ on packed volume and water retention (Table 1$)$. The difference on packed volume between the species with the highest vs. the lowest concentration (A. hebeclada vs. A. karroo) was $100 \%$ and in water retention ca. 34.2\%, (A. sieberiana vs. A. galpinii) (Table 1).

Table 1 Mean packed volume (mL/g) and water retention $(\mathrm{g} / \mathrm{g})$ of seven Acacia species grown in the Limpopo Province

\begin{tabular}{lcc}
\hline Species & Packed volume $(\mathrm{mL} / \mathrm{g})$ & Water retention $(\mathrm{g} / \mathrm{g})$ \\
\hline A. karroo & $1.50^{\mathrm{d}}$ & $3.76^{\mathrm{cd}}$ \\
A. nilotica & $2.87^{\mathrm{a}}$ & $3.84^{\mathrm{bcd}}$ \\
A. tortilis & $2.75^{\mathrm{ab}}$ & $3.89^{\mathrm{bcd}}$ \\
A. galpinii & $2.50^{\mathrm{bc}}$ & $3.71^{\mathrm{d}}$ \\
A. sieberiana & $2.87^{\mathrm{a}}$ & $4.98^{\mathrm{a}}$ \\
A. hebeclada & $3.00^{\mathrm{a}}$ & $4.31^{\mathrm{b}}$ \\
A. rhemniana & $2.37^{\mathrm{c}}$ & $4.21^{\mathrm{bc}}$ \\
s.e. & 0.082 & 0.146 \\
\hline
\end{tabular}

a, b, c, d Column means with common superscripts do not differ $(\mathrm{P}>0.05)$; $\mathrm{n}=5$ per species 
Crude protein (CP) levels differed by ca. 44\% between the species with the highest (A. sieberiana) and that with the lowest (A. rhemniana) concentration (Table 2). Acacia tortilis had the highest neutral and acid detergent fibre levels, which were $21.5 \%$ higher than that in A. rhemniana, the species with lowest NDF, and 25.3\% more than in A. karroo, the species with the lowest ADF (Table 2).

Table 2 Mean dry matter (DM), organic matter (OM), crude protein (CP), neutral detergent fibre (NDF) and acid detergent fibre (ADF) in seven Acacia species $(n=5)$

\begin{tabular}{lccccc}
\hline Species & $\begin{array}{c}\mathrm{DM} \\
(\mathrm{g} / \mathrm{kg})\end{array}$ & $\begin{array}{c}\mathrm{OM} \\
(\mathrm{g} / \mathrm{kg} \mathrm{DM})\end{array}$ & $\begin{array}{c}\mathrm{CP} \\
(\mathrm{g} / \mathrm{kg} \mathrm{DM})\end{array}$ & $\begin{array}{c}\mathrm{NDF} \\
(\mathrm{g} / \mathrm{kg} \mathrm{DM})\end{array}$ & $\begin{array}{c}\text { ADF } \\
(\mathrm{g} / \mathrm{kg} \mathrm{DM})\end{array}$ \\
\hline A. karroo & $945.4^{\mathrm{f}}$ & $897.0^{\mathrm{b}}$ & $108.0^{\mathrm{d}}$ & $504.6^{\mathrm{cd}}$ & $406.9^{\mathrm{e}}$ \\
A. nilotica & $951.6^{\mathrm{d}}$ & $882.6^{\mathrm{cd}}$ & $151.7^{\mathrm{c}}$ & $572.0^{\mathrm{b}}$ & $472.2^{\mathrm{b}}$ \\
A. tortilis & $947.7^{\mathrm{e}}$ & $864.6^{\mathrm{e}}$ & $150.2^{\mathrm{c}}$ & $621.7^{\mathrm{a}}$ & $544.9^{\mathrm{a}}$ \\
A. galpinii & $944.5^{\mathrm{g}}$ & $886.7^{\mathrm{bc}}$ & $149.6^{\mathrm{c}}$ & $509.0^{\mathrm{c}}$ & $454.7^{\mathrm{bc}}$ \\
A. sieberiana & $970.2^{\mathrm{b}}$ & $887.8^{\mathrm{bc}}$ & $183.2^{\mathrm{a}}$ & $561.3^{\mathrm{b}}$ & $414.9^{\mathrm{de}}$ \\
A. hebeclada & $971.8^{\mathrm{a}}$ & $915.1^{\mathrm{a}}$ & $164.9^{\mathrm{b}}$ & $570.1^{\mathrm{b}}$ & $428.8^{\mathrm{cde}}$ \\
A. rhemniana & $957.4^{\mathrm{c}}$ & $874.0^{\mathrm{de}}$ & $102.7^{\mathrm{e}}$ & $487.9^{\mathrm{d}}$ & $441.6^{\mathrm{bcd}}$ \\
Standard error & 0.017 & 0.373 & 0.123 & 0.627 & 0.988 \\
\hline
\end{tabular}

a, b, c, d, e, f Column means with common superscripts do not differ $(\mathrm{P}>0.05)$

There were significant species differences in the in vitro enzymatic degradability of the DM and OM of the foliage (Table 3). Acacia sieberiana had the highest DM and OM degradabilities which were ca. 54.7 and 86. 3\%, respectively, higher than that of A. tortilis (Table 3).

Table 3 Mean in vitro enzymatic dry matter (DMD) and organic matter degradability (OMD) of seven Acacia species grown in the Limpopo Province

\begin{tabular}{lcc}
\hline Species & DMD $(\mathrm{g} / \mathrm{kg} \mathrm{DM})$ & OMD $(\mathrm{g} / \mathrm{kg} \mathrm{DM})$ \\
\hline A. karroo & $460.9^{\mathrm{b}}$ & $428.9^{\mathrm{b}}$ \\
A. nilotica & $363.9^{\mathrm{e}}$ & $325.3^{\mathrm{e}}$ \\
A. tortilis & $345.4^{\mathrm{f}}$ & $254.4^{\mathrm{f}}$ \\
A. galpinii & $383.7^{\mathrm{d}}$ & $350.9^{\mathrm{d}}$ \\
A. sieberiana & $534.2^{\mathrm{a}}$ & $473.9^{\mathrm{a}}$ \\
A. hebeclada & $426.2^{\mathrm{c}}$ & $396.4^{\mathrm{c}}$ \\
A. rhemniana & $353.9^{\mathrm{ef}}$ & $315.3^{\mathrm{e}}$ \\
Standard error & 3.28 & 3.67
\end{tabular}

Column means with common superscripts do not differ $(\mathrm{P}>0.05)$

There were significant species differences in total phenolics, simple phenolics, extracted CT and total CT concentrations in NDF and ADF solutions and radial diffusion (Table 4). All Acacia species except A. tortilis had low levels of both total phenolics and simple phenolics (Table 4). Extracted CT differed by ca. 98.6\% between the species with the highest (A. karroo) and lowest (A. hebeclada) concentrations (Table 4). Acacia karroo had the highest proanthocyanidin concentrations in both ADF and NDF solutions compared to $A$. sieberiana (Table 4). Acacia tortilis had the highest radial diffusion measurement and $A$. hebeclada had the lowest (Table 4). 
All samples produced relatively flat curves in the potassium iodate test (Figure 1). Acacia nilotica had a distinct peak after $21 \mathrm{~min}$ whilst $A$. tortilis and $A$. karroo had curves with several peaks, the first appearing after $6 \mathrm{~min}$. Acacia rhemniana, A. galpinii, A. hebeclada and A. sieberiana developed no peaks at all and generally showed no reaction to the potassium iodate.

Table 4 Mean concentration of total phenolics, simple phenolics, extracted condensed tannin (ECT), condensed tannin in neutral detergent fibre (CTNDF), condensed tannin in acid detergent fibre (CTADF), and measurement of radial diffusion assay in seven Acacia species

\begin{tabular}{lcccccc}
\hline Species & $\begin{array}{c}\text { Total } \\
\text { phenolics } \\
(\mathrm{g} / \mathrm{kg} \mathrm{DM})\end{array}$ & $\begin{array}{c}\text { Simple } \\
\text { phenolics } \\
(\mathrm{g} / \mathrm{kg} \mathrm{DM})\end{array}$ & $\begin{array}{c}\text { ECT } \\
(\mathrm{g} / \mathrm{kg} \mathrm{DM})\end{array}$ & $\begin{array}{c}\text { CTNDF } \\
(\mathrm{g} / \mathrm{kg} \mathrm{DM})\end{array}$ & $\begin{array}{c}\text { CTADF } \\
(\mathrm{g} / \mathrm{kg} \mathrm{DM})\end{array}$ & $\begin{array}{c}\text { Radial } \\
\text { diffusion } \\
\left(\mathrm{cm}^{2} / \mathrm{g}\right)\end{array}$ \\
\hline A. karroo & $31.3^{\mathrm{c}}$ & $8.9^{\mathrm{d}}$ & $80.7^{\mathrm{a}}$ & $38.9^{\mathrm{a}}$ & $24.1^{\mathrm{a}}$ & $233.3^{\mathrm{b}}$ \\
A. nilotica & $25.4^{\mathrm{d}}$ & $7.5^{\mathrm{e}}$ & $44.3^{\mathrm{c}}$ & $25.9^{\mathrm{c}}$ & $18.3^{\mathrm{b}}$ & $113.3^{\mathrm{c}}$ \\
A. tortilis & $89.7^{\mathrm{a}}$ & $13.9^{\mathrm{c}}$ & $5.0^{\mathrm{f}}$ & $19.8^{\mathrm{d}}$ & $16.3^{\mathrm{c}}$ & $267.5^{\mathrm{b}}$ \\
A. galpinii & $23.4^{\mathrm{d}}$ & $23.1^{\mathrm{a}}$ & $57.1^{\mathrm{b}}$ & $31.9^{\mathrm{b}}$ & $16.4^{\mathrm{c}}$ & $321.7^{\mathrm{a}}$ \\
A. sieberiana & $12.5^{\mathrm{e}}$ & $7.6^{\mathrm{e}}$ & $10.4^{\mathrm{e}}$ & $4.4^{\mathrm{f}}$ & $3.3^{\mathrm{f}}$ & $100.8^{\mathrm{c}}$ \\
A. hebeclada & $11.2^{\mathrm{e}}$ & $7.6^{\mathrm{e}}$ & $1.1^{\mathrm{g}}$ & $4.5^{\mathrm{f}}$ & $3.5^{\mathrm{f}}$ & $55.0^{\mathrm{d}}$ \\
A. rhemniana & $39.6^{\mathrm{c}}$ & $16.1^{\mathrm{b}}$ & $25.6^{\mathrm{d}}$ & $11.4^{\mathrm{e}}$ & $8.3^{\mathrm{e}}$ & $250.0^{\mathrm{b}}$ \\
Standard error & 0.101 & 0.40 & 1.02 & 0.54 & 0.30 & 13.09
\end{tabular}

a,b, c, d, e, f Column means with common superscripts do not differ $(\mathrm{P}>0.05)$

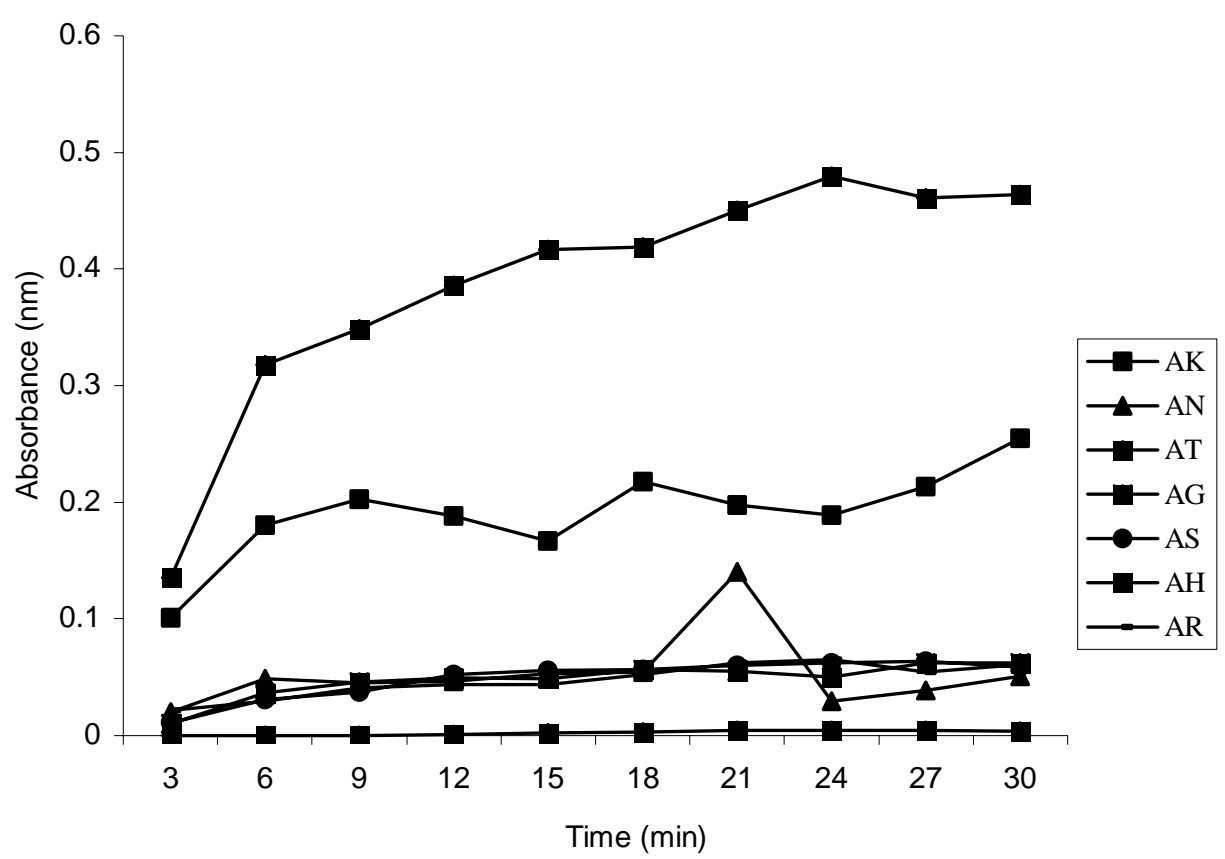

Figure 1 Profiles of hydrolysable tannins in Acacia karroo (AK), Acacia nilotica (AN), Acacia tortilis (AT), Acacia galpinii (AG), Acacia sieberiana (AS), Acacia hebeclada (AH) and Acacia rhemniana (AR) 
Dry matter degradability was strongly negatively correlated $(\mathrm{P}<0.05)$ to total phenolics and CTs in ADF (Table 5). Radial diffusion was strongly positively correlated to simple phenolics and weakly positively correlated to both total phenolics and CT in the NDF solution (Table 5). Condensed tannins were strongly positively correlated to both CTs in NDF and ADF whilst the CTs in NDF and ADF were both strongly correlated to one another (Table 5).

Table 5 Pair-wise correlation coefficients for chemical and degradation parameters of Acacia species

\begin{tabular}{|c|c|c|c|c|c|c|c|}
\hline Parameters & DMD & ТOTP & SP & $\mathrm{RD}$ & NDFCT & ADFCT & CT \\
\hline DMD & - & & & & & & \\
\hline ТОТР & $-0.71^{*}$ & - & & & & & \\
\hline SP & NS & NS & - & & & & \\
\hline RD & NS & $0.53^{*}$ & $0.81 *$ & - & & & \\
\hline NDFCT & NS & NS & NS & $0.53^{*}$ & - & & \\
\hline ADFCT & $-0.59 *$ & NS & NS & NS & $0.96 *$ & - & \\
\hline $\mathrm{CT}$ & NS & NS & NS & Ns & $0.89 *$ & $0.78 *$ & - \\
\hline
\end{tabular}

DMD - in vitro enzymatic dry matter degradability; TOTP - total phenolics; SP - simple phenolics; RD - radial diffusion; NDFCT - condensed tannins in neutral detergent fibre; ADFCT - condensed tannins in acid detergent fibre; CT - condensed tannins; NS - non-significant; ${ }^{*}=\mathrm{P}<0.05$

\section{Discussion}

The nutritive value of forages for livestock feeding depends on the balance between the nutritive components of the plants, the digestibility of such nutrients, the metabolism of absorbed nutrients and the quantity of nutrients ingested by the animal (Seoane et al., 1981). In order to decrease the cost and time involved in in vivo forage evaluation, laboratory procedures have been developed. Chemical and physical analyses contribute to determine the nutritive value and have been suggested as alternative ways to determine quality of feedstuffs (Van Soest, 1983).

Physical analyses such as packed volume and water retention influence the bulk effects of feeds. It has been postulated that in legume species, a packed volume of less than $2.98 \mathrm{~mL} / \mathrm{g}$ and a water retention of less than $6.45 \mathrm{~g} / \mathrm{g}$ would be associated with a high voluntary intake by ruminants (Seoane et al., 1981). The packed volumes ranging from 1.50 to $3.00 \mathrm{~mL} / \mathrm{g}$ and water retention of between 3.71 and $4.98 \mathrm{~g} / \mathrm{g}$ recorded in the present study suggested that the potential voluntary intakes by ruminants of the foliage of all the Acacia species studied should be high.

The CP concentration in feedstuffs is often the constituent with the most pronounced effect on the performance of animals on veld. The CP concentrations of the tree legumes in our study, $102.68-183.18 \mathrm{~g} / \mathrm{kg}$ DM, were lower than values of 137.5 - $212.5 \mathrm{~g} / \mathrm{kg}$ DM reported for West African browse (Rittner \& Reed, 1992). However, the levels in the present study were above the minimum requirements for maintenance of between 70 and $80 \mathrm{~g} \mathrm{CP} / \mathrm{kg} \mathrm{DM}$ for ruminants (Meissner, 1997). All species except A. karroo and A. rhemniana contained more than 130 to $140 \mathrm{~g} \mathrm{CP} / \mathrm{kg} \mathrm{DM}$, which is required for high producing animals (Meissner, 1997). Low levels of the detergent fibres are associated with high voluntary DM intakes in ruminants consuming all forage diets. From our study, NDF levels varied between 438.4 and $621.7 \mathrm{~g} / \mathrm{kg}$ DM among the different species. Wide variations in NDF levels in browse have been observed in other studies (Reed et al., 1990; Tanner et al., 1990; Kaitho et al., 1997; Larbi et al., 1998; Maasdorp et al., 1999; Hove et al., 2001). The higher NDF levels recorded in our study could be due to the inclusion of petioles in the foliage of all species tested.

Plant secondary compounds play a more significant role in tropical animal production than in temperate climate because tropical plants tend to have higher levels of these compounds. Simple phenolics have minimal 
impact on ruminant nutrition compared to tannins (Reed, 1995). Acacia tortilis had the highest total phenolics content, which can have a toxic effect on ruminants. It is, however, more important from a nutritional perspective to consider tannins in terms of CT and HT tannins (Mueller-Harvey, 2001). Condensed tannins are polymers of flavonol units most frequently linked at C4 - C8 or C4 - C6. They interfere with intake and digestion of the feeds in which they occur (Dube et al., 2001) at high levels, but at very low levels most have beneficial effects (Foo et al., 1996). The ideal CT concentration for ruminant animal nutrition has been suggested to be in the range 20 to $40 \mathrm{~g} / \mathrm{kg} \mathrm{DM}$, based on the butanol-HCl method (Barry \& Duncan, 1984). Acacia galpinii and A. karroo contained high levels of extracted CTs (80.7 and $57.1 \mathrm{~g} / \mathrm{kg}$ DM) compared to the range considered nutritionally safe (Barry \& Manley, 1986; Reed, 1995). All species from our study had low concentration of CT in ADF and NDF. Thus, they can be considered to be nutritionally safe. The study showed that more CTs exist in bound form in NDF compared to ADF and that NDF represents not only hemicellulose, cellulose, lignin and silica fractions but also proanthocyanidins in the leaves of tree species. Moreover, the presence of CT at high concentrations in the fibre fractions may affect their digestion kinetic parameters and confound the relationship between kinetic measurements and fibre composition (Makkar \& Singh, 1991).

Hydrolysable tannins are esters of a sugar, usually glucose and a phenolic acid such as gallic acid in gallotannins and hexahydrodiphenic acid in ellagitannin. The HTs are known to be toxic to ruminants (Dollahite et al., 1962; Holliman, 1985; Shi, 1988). Recent studies showed that HTs may have inhibitory effects on various enzymes (Yoshida et al., 2000). All the tree legume species from our study except A. nilotica had low levels of HTs mainly due to gallotannins which have a lower sensitivity to potassium iodate and hence lower absorbance than ellagitannins (Willis \& Allen, 1998). Acacia nilotica contained a higher level of HTs, mostly, according to Mueller-Harvey et al. (1987), as the phenolics, catechin gallates.

Methods that determine the ability of tannins to precipitate proteins are better tools for nutritional studies than colorimetric methods (Mueller-Harvey, 2001). The radial diffusion assay (Hagerman, 1987) is a protein precipitation method that depends on the formation of tannin complexes with bovine serum albumin embedded in an agar and allowed to diffuse through the agar.

In vitro digestibility is the disappearance of DM after $48 \mathrm{~h}$ incubation with rumen microorganisms. The DM degradability value obtained in the current study for A. sieberiana was within the range of 500 to $560 \mathrm{~g} / \mathrm{kg}$ DM, which was reported by Mullen (1999) as adequate to meet the energy requirements for non-productive ruminants and at low levels of production. The other species showed medium to low in vitro enzymatic degradability. This suggested that the tannin content and fibre content of the Acacia species negatively affected the nutritive value of the forages. The measured DM degradability was negatively correlated to both total phenolics and CTs in ADF solution, whilst there was a positive correlation between different types of tannins assays. This is because trees and shrubs containing high levels of tannin tend to have a low DM degradability and therefore a low voluntary intake by ruminants.

These results suggested that the nutrient composition of Acacia species from the Limpopo Province was above the minimum requirements for ruminants. The practical implication is that smallholder farming systems could benefit from a feed resource that includes harvesting of Acacia species and utilizing them during the dry seasons when there is a shortage of protein.

\section{Conclusion}

The in vitro degradability of the tree foliages from the Acacia species used in the experiment ranged from low to medium, despite their high intake potential based on packed volume and water retention, high protein and low detergent fibre levels. The low nutritive value was attributed to a combination of type and amount of tannins present in foliage. It is proposed that there is a need for differentiation of tannins in terms of chemical structure, since chemical analyses could not adequately explain the observed differences in nutritive value. 


\section{Acknowledgements}

The senior author acknowledges financial support for scholarship from National Research Foundation and Departments of Botany and Biochemistry, University of The North, (now University of Limpopo) for using apparatus free of charge.

\section{References}

Abdulrazak, S.A., Muinga, R.W., Thorpe, W. \& Ørskov, E.R., 1996. The effects of supplementation with Gliricidia sepium or leucaena lucocephala on intake, digestion and live-weight gains of Bos taurus x Bos indicus steers offered napier grass. Anim. Feed Sci. Technol. 63, 381-388.

AOAC, 1984. Official methods of analysis (14th ed.). Association of Official Analytical Chemists, Inc., Arlington, Virginia, USA.

Aufrere, J. \& Michalet-Doreau, B., 1988. Comparison of methods for predicting digestibility of feeds. Anim. Feed Sci. Technol. 20, 203-218.

Barry, T.N. \& Duncan, S.J., 1984. The role of condensed tannins in the nutritional value of Lotus pedunculatus for sheep. I Voluntary intake. Br. J. Nutr. 57, 485-491.

Barry, T.N. \& Manley, T.R., 1986. Interrelationships between the concentrations of total condensed tannin, free condensed tannin and lignin in Lotus sp., and their possible consequences in ruminant nutrition. J. Sci. Food Agric. 37, 248-254.

Dollahite, J.W., Pigeon, R.F. \& Camp, B.J., 1962. The toxicity of gallic acid, pyrogallol, tannic acid and quercus havardi in the rabbit. Am. J. Vet. Res. 23, 1264.

Dube, J.S., Reed, J.D. \& Ndlovu, L.R., 2001. Proanthocyanidins and other phenolics in Acacia leaves of Southern Africa. Anim. Feed Sci. Technol. 91, 59-67.

Foo, L.Y., Newman, R., Waghorn, G.C., McNabb, W.A. \& Ulyatt, M.J., 1996. Proanthocyanidins from lotus corniculatus. Phyt. 41, 617-624.

Hagerman, A.E., 1987. Radial diffusion method for determining tannin in plant extracts. J. Chem. Ecol. 13, 437449.

Holliman, A., 1985. Acorn poisoning in ruminants. Vet. Rec. 116, 546.

Hove, L., Topps, J.H., Sibanda, S. \& Ndlovu, L.R., 2001. Nutrient intake and utilization by goats fed dried leaves of the same legumes Acacia angustissima, Calliandra calothyrsus and Leucaena leucocephala as supplements to native pasture hay. Anim. Feed Sci. Technol. 91, 95-106.

Kaitho, R.J., Umunna, N.N., Nsahlai, I.V., Tamminga, S., Van Bruchem, T. \& Hanson, I., 1997. Palatability of wilted and dried multipurpose tree species fed to sheep and goats. Anim. Feed Sci. Technol. 65, 151-165.

Larbi, A., Smith, J.W., Kurdi, I.O., Adekunle, I.O., Raji, A.M. \& Lapido, D.O., 1998. Chemical composition, rumen degradation and gas production characteristics of some multipurpose fodder tree shrubs during wet and dry season in the humid tropics. Anim. Feed Sci. Technol. 72, 81-96.

Maasdorp, B.V., Muchenje, V. \& Titterton, M., 1999. Palatability and effect on dairy cow milk yield of dried fodder from the forage trees Acacia boliviana, Calliandra calothyrsus and Leucaena leucocephala. Anim. Feed Sci. Technol. 77, 49-59.

Makkar, H.P.S. \& Singh, B., 1991. Distribution of condensed tannin (proanthocyanidins) in various fractions in young and mature leaves of some oak species. Anim. Feed Sci. Technol. 32, 253-260.

Meissner, H.H., 1997. Recent research on forage utilization by ruminant livestock in South Africa. Anim. Feed Sci.Technol. 69, 103-119.

Mueller-Harvey, I., 2001. Analysis of hydrolysable tannins. Anim. Feed Sci. Technol. 91, 3-20.

Mueller-Harvey, I., Reed, J.D., Hartley. R.D., 1987. Characterisation of phenolic compounds, including flavonoids and tannins of 10 Ethiopian browse species by high performance liquid chromatography. J. Sci. Food Agric. 39, 1-14.

Mullen, C.L., 1999. Summer legume forage crops: Cowpea, Lablab, Soyabeans. Agfact P4, (2-16th ed.). 
Norton, B.W., 1994. Anti-nutritive and toxic factors in forage tree legumes. In: Forage Tree Legumes in Tropical Agriculture. Eds. Gutteridge, R.G. \& Shelton, H.M., CAB, London. Int., Wallingford, Oxon, UK. pp. 202215.

Porter, L.J., Hristich, L.N. \& Chan, B.G., 1986. The conversion of procyanidins and prodelphinidins to cyanidins and delphinidins. Phyt. 25, 223-230.

Reed, J.D., 1995. Nutritional toxicology of tannins and related polyphenols in forage legumes. J. Anim. Sci. 73, 1516-1528.

Reed, J.D., Soller, H., Woodward, A., 1990. Fodder tree and stover diets for sheep, intake, growth, digestibility and the effects of phenolics on nitrogen utilization. Anim. Feed Sci. Technol. 30, 39-50.

Rittner, U. \& Reed, J.D., 1992. Phenolics and in vitro degradability of protein and fibre in west African browse. J. Sci. Food Agric. 58, 21-28.

SAS, 1998. Statistical Analysis Systems user’s guide (Version 6.14), SAS Institute, Inc., Cary, N.C., USA.

Seoane, J.R., Cote, M., Gervais, P. \& Laforest, T.P., 1981. Prediction of the nutritive value of alfalfa (Saranae), bromegrass (Saratoga) and timothy (Champ, Climax, Bounty) fed as hay to growing sheep. Can. J. Anim. Sci. 61, 403-413.

Shi, Z.C., 1988. Identification of the phenolics substances in bovine urine associated with oak leaf poisoning. Res. Vet. Sci. 45, 152-155.

Tanner, T.C., Reed, J.D. \& Owen, E., 1990. The nutritive value of fruits (pods and seeds) from Acacia species compared with extracted nough (Guizonia abysinica) meal as supplement to maize stover for Ethiopian highland sheep. Anim. Prod. 51, 122-133.

Van Soest, P.J., 1983. Nutritional Ecology of Ruminants. O \& B Books, Corvallis, Oregon, USA.

Van Soest, P.J., Robertson, J.B. \& Lewis, B.A., 1991. Methods for dietary fiber, neutral detergent fiber and nonstarch polysaccharide (NSP) in relation to animal nutrition. J. Dairy Sci. 74, 3583-3597.

Waterman, P.G. \& Mole, S., 1994. Analysis of phenolics plant metabolites. Blackwell, Oxford, UK.

Willis, R.B. \& Allen, P.R., 1998. Improved methods for measuring hydrolysable tannins using potassium iodate. Analyst 123, 435-439.

Yoshida, T., Hatano, T. \& Ito, H., 2000. Chemistry and function of vegetable polyphenols with high molecular weights. BioFactors 13, 121-125. 